\title{
ANALISIS PENGARUH PROMOSI PENJUALAN, PENATAAN PRODUK, DAN SUASANA MALL TERHADAP PEMBELIAN TIDAK TERENCANA (STUDI KASUS RAMAYANA DEPARTMENT STORE YOGYAKARTA)
}

\author{
Wuri Plangi Ayatina \\ Saptaningsih Sumarmi \\ Universitas PGRI Yogyakarta \\ saptaningsih@yahoo.co.id
}

\begin{abstract}
This study aims to analysis determine the effect of sales promotion, display product, and store atmosphere on impulse buying at the Ramayana Department Store Yogyakarta. This research was conducted at the Ramayana Department Store Yogyakarta in November 2018 until June 2019. This research was a quantitative study with 80 respondents. Data collection techniques is done by questionnaires and observation. The analysis technique used in this study uses multiple linear regression analysis. The results of this study concluded that sales promotion, display product, and store atmosphere has a positive and sign effect on impulse buying through partial testing and simultaneous testing.
\end{abstract}

Keywords: Sales Promotion; Display Product; Store Atmosphere; Impulse Buying.

PENDAHULUAN

Perkembangan teknologi dan keterbukaan informasi yang menjadi salah satu konsekuensi adanya globalisasi membuat persaingan di segala bidang usaha sangat ketat. Munculnya e-commerce yang memberikan akses kemudahan bagi konsumen mampu menjadikan tantangan baru bagi pelaku usaha untuk merumuskan strategi agar tetap bisa bertahan. Ketatnya persaingan tidak menjadikan pelaku usaha konvensional berhenti untuk berekspansi, meskipun banyak department store di Indonesia yang melakukan penutupan. Salah satu department store di Indonesia yang melakukan penutupan adalah Ramayana Department Store. Penutupan dilakukan oleh manajemen dengan cara menghentikan operasionalnya karena mengalami kerugian (Reza, 2017).
Hal ini bukan akibat daya beli konsumen yang menurun, melainkan karena perubahan tren ritel global (e-commerce). Dengan berkembangnya tren e-commerce maka konsumen mulai senang memasuki toko-toko online. Selain lebih praktis, pilihan barang yang dijual lebih banyak variasinya, harga yang ditawarkan jauh lebih murah dengan diskon yang menarik, dan tidak perlu untuk mengantri pada saat melakukan pembayaran.

Daerah Istimewa Yogyakarta (DIY) dikenal sebagai kota pelajar, kota budaya, kota kuliner dan kota pariwisata, dan menjadi pilihan bagi wisatawan lokal maupun mancanegara. Meskipun tergolong sebuah kota kecil, DIY memiliki sarana dan prasarana yang sangat memadai. Hampir setiap lima tahun sekali, muncul pusat perbelanjaan baru di wilayah DIY, seperti Sleman City Hall, Jogja City Mall, Hartono Mall, Matahari Mall, Ambarukmo Plaza, Lippo Plaza, Galeria Mall, Jogjatronik Mall, Sahid J-Walk, Transmart Carrefour, 
Jogja Town Square, dan Ramayana Mall. Hal di atas masih diramaikan dengan hadirnya supermarket Loko, Superindo, Giant, Hero, Ramai, dan Gardena. Meningkatnya berbagai department store perlengkapan diri konsumen pada fashion menjadi faktor pendorong pertama yang memunculkan keinginan masyarakat untuk membeli sangat tinggi. Sektor fashion mengalami peningkatan signifikan dalam sektor ritel yang dibuktikan dengan semakin banyaknya perusahaan fashion yang membuka usahanya di berbagai tempat di Yogyakarta.

Pra survey dilakukan terhadap pusat perbelanjaan di DIY, khususnya department store yang merupakan pemain lama dan masih bertahan meskipun bermunculan pemain baru. Berdasarkan pra survei tersebut, pelajar merupakan target utama sasaran department store untuk menawarkan produknya. Pada usia tersebut, timbul berbagai kemungkinan seseorang mengalami perubahan-perubahan, baik perubahan fisik, sikap, perilaku maupun emosinya. Dalam hal melakukan pembelian perilaku seperti ini cenderung mendorong pembelian tidak terencana. Era dimana orang membeli barang bukan karena nilai bermanfaatnya namun karena gaya hidup.

Pada dasarnya sukses tidaknya suatu bisnis tergantung pada kita cukup memberikan perhatian terhadap yang dibutuhkan dan diinginkan orang yang menjadi sasaran bisnis kita. Untuk itu seorang manajer harus selalu berinovasi terus menerus dan menerapkan strategi yang menetap agar bisnis tersebut dapat berkembang dengan baik. Selain itu, untuk meningkatkan daya beli konsumen perlu adanya promosi, diskon, dan tempat berbelanja yang nyaman.

Ramayana Department Store merupakan salah satu pemain lama yang bergerak di bidang usaha department store dan berlokasi strategis yaitu di kawasan wisata Malioboro, dan bahkan baru saja membuka cabang dengan target Ramayana Premium di Sleman City Hall. Ramayana Department Store menjual berbagai produk fashion, mulai dari pakaian anak, pakaian dewasa hingga sandal dan sepatu. Ramayana berdiri pertama kali pada 24 Februari 1993 dengan nama Robinson Department Store (Honezty, 2008). Pada tahapan perkembangan cukup pesat, Ramayana mengganti nama menjadi Ramayana Department Store. Salah satu kekuatan Ramayana adalah memiliki lokasi di kawasan daerah tujuan wisata andalan DIY, yaitu Malioboro. Berbagai upaya dilakukan manajemen tentang bagaimana mereka dapat mempertahankan posisi saingnya. Berdasarkan hasil survei dan observasi terhadap Ramayana, penataan produk mereka kurang menarik, kondisi dalam toko kurang tertata dengan baik, dan kegiatan promosi dengan menggunakan speaker di area perbelanjaan terlalu bising. Namun dengan masih bertahannya outlet ini dari tahun 1993 sampai sekarang menandakan bahwa usaha ini masih membukukan keuntungan bagi pemiliknya.

Wawancara singkat dengan tim manajemen Ramayana, bahwa pemahaman Ramayana Department Store mengenai proses pembelian yang dilakukan konsumen merupakan hal penting untuk mempertahankan pelanggan yang sudah ada. Tim manajemen mencoba mempengaruhi konsumen atau pelanggan untuk melakukan pembelian adalah dengan memunculkan pembelian tidak terencana. Pembelian tidak terencana merupakan suatu pembelian secara tiba-tiba tanpa ada paksaan dari orang lain. Konsumen dalam melakukan pembelian tidak direncanakan muncul pembelian yang didasari oleh faktor emosi pada diri konsumen (Utami, 2015). Pembelian tidak terencana yang didorong oleh emosional, daya tarik, dan penglihatan utama muncul saat memasuki Ramayana Department Store. Untuk dapat mendorong pembelian tidak terencana, perusahaan harus menciptakan strategi untuk merangsang pembelian. Salah satu upaya Ramayana Departemen Store untuk mempengaruhi konsumen melakukan pembelian tidak direncana dengan melakukan promosi penjualan. Promosi penjualan yang dilakukan berupa potongan harga penjualan (diskon), hadiah, kupon, dan promo hari-hari tertentu untuk mempengaruhi pembelian dan 
menarik perhatian konsumen yang datang ke Ramayana Departemen Store.

Selanjutnya perusahaan juga memperhatikan tampilan guna untuk menarik perhatian konsumen dan menciptakan suasana mall yang nyaman untuk menciptakan pengalaman berbelanja yang menyenangkan kepada konsumen. Ramayana menggunakan latar belakang musik, pengharum ruangan, serta lingkungan mall ditata serapi mungkin agar konsumen tidak merasa jenuh. Penataan produk merupakan tata letak yang melambangkan unsur produk baik, keindahan dan kerapihan agar terkesan menarik saat dipandang, sehingga mendorong konsumen untuk membelinya.

Berorientasi pada faktor-faktor yang dapat mempengaruhi pembelian tidak terencana, upaya promosi penjualan, penataan produk dan suasana mall menjadi kunci utama suatu perusahaan untuk tetap dan memiliki konsumen yang loyal. Salah satu porsi terbesar yang berperan dalam mempengaruhi konsumen untuk pembelian tidak terencana adalah promosi penjualan, penataan produk dan suasana mall.

\section{REVIEW LITERATUR DAN HIPOTESIS}

\section{Landasan Teori}

\section{Pembelian Tidak Terencana}

Pembelian tidak terencana adalah perilaku pada diri konsumen dalam melakukan pembelian yang tidak direncanakan sebelumnya (Muruganantham, 2013). Salah satu bentuk perilaku konsumen yang tidak mempunyai rencana terlebih dahulu dalam melakukan pembelian secara spontan tanpa ada dorongan dari orang lain.

Menurut Mowen (2001), pengertian pembelian tidak terencana yang didefinisikan sebagai tindakan pembelian yang dilakukan tanpa ada masalah yang sebelumnya telah dikenali atau niat beli yang dibentuk sebelum memasuki mall. Dapat disimpulkan bahwa pembelian tidak terencana adalah suatu keputusan yang dibuat oleh pelanggan karena adanya stimulus dan rangsangan-rangsangan menarik yang ada di dalam Ramayana Department Store.

\section{Promosi Penjualan}

Promosi merupakan salah satu hal yang penting dalam pemasaran yang dilakukan oleh perusahaan. Oleh karena itu, perusahaan menggunakan promosi dalam perusahaannya untuk memberitahukan atau menawarkan produk atau jasa kepada calon konsumen untuk mempengaruhi konsumen dalam kegiatan pembelian sesuai keinginan atau kebutuhan konsumen.

Menurut Clow (2012) promosi penjualan terdiri dari semua insentif yang ditawarkan kepada pelanggan anggota saluran untuk mendorong pembeli produk saat ada di department store. Insentif yang ditawarkan kepada pembeli berupa pengembalian uang, kupon (voucher) yang berjangka pendek.

\section{Penataan Produk}

Penataan produk dapatmempengaruhi keinginan konsumen dalam membeli sesuatu, yang tidak didorong dengan seseorang melainkan keinginan sendiri, didorong oleh daya tarik, atau oleh penglihatan ataupun oleh perasaan lainnya (Alma, 2018). Ramayana Department Store harus melakukan dan menciptakan daya tarik ke konsumen pada penataan ruang dan penyusunan produk sehingga konsumen yang datang ke Ramayana Department Store merasakan betah dan nyaman dalam berbelanja.

Menurut Alma (2018) menyatakan display adalah usaha yang mendorong perhatian dan minat konsumen pada mall atau barang, mendorong keinginan konsumen untuk membeli melalui daya 
tarik penglihatan yang secara langsung. Memajang produk di dalam mall dan etalase mempunyai pengaruh besar terhadap penjualan.

\section{Suasana Mall}

Suasana mall adalah elemen yang terdapat di bauran pemasaran ritel yang terkait dalam hal penciptaan suasana belanja di mall (Utami, 2010). Upaya untuk merancang atau menciptakan efek emosional spesifik pada pembeli yang meningkatkan peluang pembelian di Ramayana Department Store.

Menurut Nofiawaty (2014) suasana mall adalah desain lingkungan yang berada di suatu mall melalui pencahayaan, warna, musik, tata letak, arsitektur ruangan, pengharum ruangan untuk merancang respon emosional, dan presepsi pelanggan yang ada di Ramayana Department Store dalam melakukan pembelian produk. Berdasarkan dari beberapa yang menjelaskan tentang suasana mall, maka definisi tersebut dapat disimpulkan bahwa suasana mall adalah elemen yang terdapat pada lingkungan mall melalui penciptaan suasana seperti pencahayaan, warna, musik, tata letak, arsitektur ruangan, dan pengharum ruangan.

\section{Hipotesis}

\section{Pengaruh Positif Promosi Penjualan} terhadap Pembelian Tidak Terencana

Promosi penjualan adalah suatu komunikasi informasi yang digunakan oleh perusahaan untuk mempromosikan produk atau barang ke konsumen dengan tujuan untuk merubah sikap dan tingkah laku pembeli, yang sebelumnya tidak paham menjadi paham sehingga menjadi pembeli dan mengingat produk tersebut (Kurniawan, 2013). Promosi penjualan yang dilakukan perusahaan dengan memberikan diskon dan cashback pada produk yang dijual dapat menjadikan pengunjung dapat tertarik dan berminat membeli karena konsumen sangat senang membeli barang yang sedang didiskon, meskipun semula konsumen tidak berminat memberi barang tersebut.

Pembelian tidak terencana dapat diartikan sebelumnya dengan memiliki kecenderungan konsumen membeli dengan spontan, reflek, tiba-tiba, otomatis, dan konsumen melakukan pembelian tidak terencana dapat terjadi dimana dan kapanpun. Seorang konsumen saat melakukan pembelian tidak terencana dalam mengambil keputusan untuk membeli produk hanya berpikir jangka pendek untuk membeli. Penelitian ini mendukung penelitian sebelumnya yang dilakukan oleh Temaja (2015) dan Oky (2016) yang menunjukkan bahwa promosi penjualan berpengaruh positif terhadap pembelian tidak terencana.

\section{H1 :Terdapat Pengaruh Positif Promosi Penjualan terhadap Pembelian Tidak Terencana.}

\section{Pengaruh Positif Penataan Produk terhadap Pembelian Tidak Terencana}

Penataan produk yang menarik, rapi, tertata akan dapat mempengaruhi psikis konsumen. Penataan produk adalah usaha yang dilakukan untuk menata barang-barang yang akan ditawarkan kepada konsumen agar merasa tertarik untuk melihat dan memutuskan untuk melakukan pembelian (Sopiah, 2008). Penataan produk bagi mall bertujuan untuk menarik perhatian konsumen dengan cara menggunakan tata letak barang yang menarik. Sedangkan pembelian tidak terencana adalah tindakan pembelian yang sebelumnya tidak diakui secara sadar sebagai hasil dari pertimbangan, atau niat pembelian yang terbentuk sebelumnya memasuki mall (Mowen, 2002) atau bisa juga dikatakan tiba-tiba dan tidak direncanakan sebelumnya untuk melakukan pembelian yang secara langsung tanpa banyak pertimbangan terlebih dahulu. Ramayana Department Store melakukan penataan produk untuk 
mempengaruhi konsumen melakukan pembelian spontan dengan melihat tata letak barang yang menarik sehingga konsumen melakukan pembelian tidak terencana.

Hal ini memberikan implikasi bahwa penataan produk pada Ramayana Department Store senantiasa memperhatikan unsur pengelompokkan jenis dan kegunaan produk, kerapian dan keindahan yang bertujuan untuk memudahkan konsumen dalam melakukan pencarian produk, menonjolkan jenis dan merek produk, meningkatkan penjualan dan memperkenalkan produk baru sehingga dapat memberikan manfaat yang positif bagi Ramayana Department Store. Penelitian ini mendukung hasil penelitian sebelumnya yang dilakukan oleh Potoh (2017) yang menunjukkan penataan produk berpengaruh positif terhadap pembelian tidak terencana.

\section{H2 :TerdapatPengaruh PositifPenataan Produk terhadap Pembelian Tidak Terencana}

\section{Pengaruh Positif Suasana Mall terhadap Pembelian Tidak Terencana}

Suasana mall berpengaruh positif terhadap pembelian tidak terencana karena memiliki program yang baik, yaitu membuat suasana Ramayana Department Store menjadi lebih tertata dengan lebih baik, pencahayaan, bersih, dan berpendinginan udara. Keberadaan kondisi di atas akan menambah minat konsumen untuk lebih betah berada di mall, sehingga dapat menimbulkan pembelian tidak terencana.

Suasana mall berarti bauran pemasaran ritel yang terkait dalam hal penciptaan suasana belanja. Suasana mall merupakan kunci dalam menarik dan membuat konsumen terkesan dengan pengalaman berbelanja di dalam gerai (Coley, 2003). Ramayana Department Store mampu mengelola suasana mallnya dengan sedemikian rupa sehingga meningkatkan kunjungan konsumen. Oleh karena itu, Ramayana Department Store harus membuat suasananya terlihat menarik saat dikunjungi konsumen. Sedangkan pembelian tidak terencana bagi perusahaan adalah konsumen yang melakukan pembelian di Ramayana Department Store dengan didukung adanya suasana mall yang nyaman, pencahayaan, pendingin ruangan, dan tata warna dalam mall tersebut mempengaruhi konsumen dalam melakukan pembelian tidak terencana. Penelitian ini mendukung hasil penelitian sebelumnya yang dilakukan oleh Oky (2015) dan Temaja (2015) yang menunjukkan bahwa suasana mall berpengaruh positif terhadap pembelian tidak terencana.

H3 :Terdapat Pengaruh Positif Suasana Mall terhadap Pembelian Tidak Terencana

4. Pengaruh Signifikan Promosi Penjualan, Penataan Produk, dan Suasana Mall secara Simultan terhadap Pembelian Tidak Terencana

H4 :Terdapat Pengaruh Signifikan Promosi Penjualan, Penataan Produk, dan Suasana Mall secara Simultan terhadap Pembelian Tidak Terencana

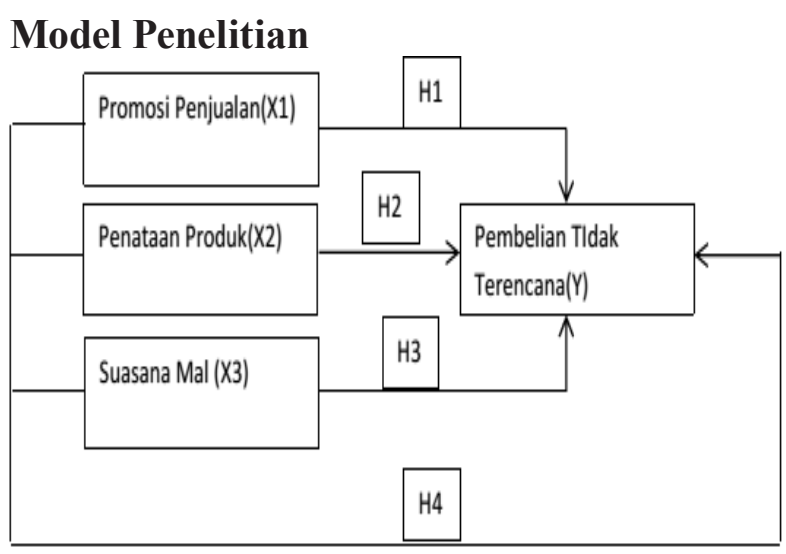

Gambar 2.1. Model Penelitian 


\section{METODE PENELITIAN}

\section{Populasi dan Sampel}

Menurut Sugiyono (2010) populasi adalah wilayah generasi yang terdiri atas obyek atau subyek yang mempunyai kualitas dan karakteristik tertentu yang ditetapkan oleh peneliti untuk dipelajari dan kemudian ditarik kesimpulannya. Dalam penelitian ini populasi yang dimaksud adalah semua konsumen yang melakukan pembelian tidak terencana di Ramayana Department Store Yogyakarta. Oleh karena itu, populasi merupakan populasi tak terbatas atau tak hingga karena tidak dapat diketahui secara pasti ukuran populasi sebenarnya dari konsumen yang melakukan pembelian tidak terencana di Ramayana Department Store Yogyakarta.

Menurut Sugiyono (2013) sampel adalah bagian dari jumlah atau karakteristik yang dimiliki oleh populasi tersebut. Bila populasi besar, tidak mungkin mempelajari semua yang ada dipopulasi, misalnya karena keterbatasan dana, tenaga, dan waktu, maka penelitian dapat menggunakan sampel yang diambil dari populasi itu.

\section{Variabel Penelitian}

\section{Variabel Dependen}

Variabel dependen atau terikat merupakan variabel yang dipengaruhi atau yang menjadi akibat karena adanya variabel bebas (Sugiyono, 2013). Variabel dependen dalam penelitian ini adalah pembelian tidak terencana (Y).

\section{Variabel Independen}

Variabel independen merupakan variabel yang mempengaruhi atau yang menjadi sebab perubahannya atau timbulnya variabel dependen (terikat), (Sugiyono, 2013). Jadi, variabel independen ialah variabel yang mempengaruhi. Dalam penelitian ini variabel independen adalah Promosi Penjualan $\left(\mathrm{X}_{1}\right)$, Penataan Produk $\left(\mathrm{X}_{2}\right)$, dan Suasana Mall $\left(\mathrm{X}_{3}\right)$.

\section{Teknik Analisis Data \\ Uji Instrumen}

\section{Uji Validitas}

Uji Validitas digunakan untuk menunjukkan sejauh mana suatu alat pengukur itu mampu mengukur apa yang ingin diukur, maka kuesioner yang disusunnya harus mengukur apa yang ingin diukurnya. Semakin tinggi validitas suatu alat pengukur, semakin tepat pula pengukuran itu mengenai sasaran (Arikunto, 2006). Pengukuran dalam penelitian ini menggunakan data yang valid (Sugiyono, 2012). Instrumen yang valid berarti alat ukur yang digunakan oleh peneliti untuk mendapatkan hasil data yang valid. Valid yang berarti instrumen tersebut dapat digunakan untuk mengukur apa yang seharusnya diukur. Dalam menguji kevaliditasan dengan cara menyebarkan kuesioner sebanyak 30 responden terlebih dahulu untuk mengetahui pertanyaan-pertanyaan yang sudah tersedia.

Untuk mengetahui apakah suatu data valid atau tidak maka ditentukan berdasarkan kriteria sebagai berikut:

1) Jika $r_{\text {hitung }}$ positif dan $r_{\text {hitung }}>r_{\text {tabel }}$, maka variabel tersebut valid (tingkat signifikansi $5 \%$ atau 0,05 )

2) Jika $r_{\text {hitung }}$ positif dan $r_{\text {hitung }}<r$ tabel, maka variabel tersebut tidak valid (tingkat signifikansi 5\% atau 0,05)

\section{Uji Reliabilitas}

Uji reliabilitas adalah suatu angka indeks yang digunakan untuk mengukur konsistensi alat pengukur, apakah suatu pernyataan dapat dipercaya untuk digunakan sebagai alat pengumpulan data karena sudah dianggap baik. dalam analisis ini digunakan koefisien Cronbach's Alpha (Azwar, 1986). Suatu instrumen dinyatakan reliabel apabila hasil dari skor yang konsisten pada setiap pengukuran. Uji reliabilitas ini menggunakan bantuan program SPSS. Untuk mengetahui reliabel 
atau tidak digunakan kriteria sebagai berikut:
1) Jika cronbach's alpha $>0,6$ maka kuesioner tersebut dinyatakan reliabel.
2) Jika cronbach's alpha < 0,6 maka kuesioner tersebut dinyatakan tidak reliabel.

\section{Analisis Regresi Linier Berganda}

Menurut Sugiyono (2004) analisis regresi linier berganda digunakan untuk mengetahui bagaimana pengaruh regresi yang dimiliki satu variabel dependen dan dua atau lebih variabel independen. Untuk mencari pengaruh antara variabel dependen dan independen digunakan rumus regresi linier berganda dalam penelitian ini, yaitu:

$$
Y=a+\beta_{1} X_{1}+\beta_{2} X_{2}+\beta_{3} X_{3}
$$

Keterangan:

Y : Pembelian Tidak Terancana

a : Konstanta

$\mathrm{X}_{1}$ : Promosi Penjualan

$\mathrm{X}_{2}$ : Penataan Produk

$\mathrm{X}_{3}$ : Suasana Mall

$\beta_{1}$ : Koefisien Regresi $X_{1}$

$\beta_{2} \quad$ : Koefisien Regresi $X_{2}$

$\beta_{3}$ : Koefisien Regresi $X_{3}$

\section{Uji Hipotesis}

\section{Uji Parsial (Uji T)}

Menurut Ghozali (2012) uji $t$ digunakan untuk mengetahui seberapa jauh pengaruh masing-masing variabel independen (promosi penjualan, penataan produk, dan suasana mall) secara parsial atau terpisah terhadap variabel dependen (pembelian tidak terencana). Pengujian uji t dengan tingkat signifikansi (alpha) 5\% atau 0,05 . Dasar pengambilan keputusan digunakan dalam uji $\mathrm{t}$ adalah sebagai berikut:
1) Jika nilai probabilitas signifikansi $>0,05$, maka hipotesis ditolak. Hipotesis ditolak mempunyai arti bahwa variabel independen tidak berpengaruh signifikan terhadap variabel dependen.

2) Jika nilai probabilitas signifikansi $<0,05$, maka hipotesis diterima. Hipotesis diterima mempunyai arti bahwa variabel independen berpengaruh signifikan terhadap variabel dependen.

\section{Uji Simultan (Uji F)}

Uji F digunakan mengetahui apakah variabel independen (promosi penjualan, penataan produk, dan suasana mall) tersebut secara simultan atau bersamasama mempunyai pengaruh signifikan dengan pembelian tidak terencana. Menghitung $\mathrm{F}_{\text {hitung }}$ dengan rumus menurut (Siagian, 2000) berikut ini:

1) Dalam pengujian ini digunakan taraf signifikansi sebesar 5\% $(0,05)$ dan derajat kebebasan $($ d.f $)=(k-1, n-k, \alpha)$, dapat diketahui dari hasil perhitungan program SPSS.

2) Berdasarkan perbandingan nilai Fhitung dan Ftabel

a) jika $\mathrm{F}_{\text {hitung }}<\mathrm{F}_{\text {tabel }}$ maka Ho diterima berarti promosi penjualan $\left(\mathrm{X}_{1}\right)$, penataan produk $\left(\mathrm{X}_{2}\right)$, dan suasana mall $\left(\mathrm{X}_{3}\right)$ secara simultan berpengaruh terhadap pembelian tidak terencana $(Y)$.

b) Sebaliknya jika $F_{\text {hitung }}>F_{\text {tabel }}$ maka Ho ditolak berarti promosi penjualan $\left(\mathrm{X}_{1}\right)$, penataan produk $\left(\mathrm{X}_{2}\right)$, dan suasana mall $\left(\mathrm{X}_{3}\right)$ secara simultan berpengaruh terhadap pembelian tidak terencana $(\mathrm{Y})$.

\section{Uji Koefisien Determinan}

Menurut Ghozali (2012) koefisien determinasi $\left(\mathrm{R}^{2}\right)$ merupakan alat yang digunakan untuk mengetahui seberapa jauh pengaruh variabel independen yang terdiri dari promosi penjualan, penataan produk, dan suasana mall dengan variabel dependen pembelian tidak terencana atau mengetahui besar pengaruh variabel bebas terhadap variabel terikat. 
Dalam ananlisis regresi linier berganda koefisien determinasi dapat digunakan untuk mengukur prosentase pengaruh variabel penjelas yang masuk ke dalam model terhadap variasi naik turunnya variabel Y secara bersama.

1) Nilai $R^{2}$ selalu positif merupakan rasio dan dua jumlah kuadrat (yang nilainnya selalu positif)

2) Nilai $0 \leq R^{2} \geq 1$

$\mathrm{R}^{2}=0$ berarti tidak ada hubungan antara $\mathrm{X}$ dan $\mathrm{Y}$, atau model regresi yang terbentuk tidak dapat untuk meramalkan $\mathrm{Y} 0=1$ berarti garis regresi yang terbentuk dapat meramalkan Y secara sempurna.

\section{HASIL PENELITIAN DAN PEMBAHASAN}

\section{Uji Instrumen}

\section{Uji Validitas}

Dalam penelitian ini, menunjukkan 30 responden yang diuji untuk mengetahui validitas suatu instrumen pernyataan. Suatu item pernyataan apabila koefisien validitasnya kurang dari 0,30 biasanya dianggap tidak valid (Sugiyono, 2013). Jadi, suatu item pernyataan dianggap valid apabila nilai pearson correlation $>$ 0,30 .

Pengujian validitas ini dinyatakan signifikan apabila nilai $p$-value berada di bawah dari tarif signifikasi, yaitu ( $\alpha$ $=0,05)$ (Ghozali, 2012). Pernyataan dalam kuesioner ini terdiri dari 4 butir item pernyataan mengenai promosi penjualan $\left(\mathrm{X}_{1}\right), 4$ butir item pernyataan mengenai penataan produk $\left(\mathrm{X}_{2}\right), 5$ butir item pernyataan mengenai suasana mall $\left(\mathrm{X}_{3}\right)$, dan 5 item pernyataan mengenai pembelian tidak terencana (Y). Hasil pegujian validitas dapat dilihat di bawah ini:
Tabel 4.1

Uji Validitas

\begin{tabular}{|c|c|c|c|}
\hline Variabel & Instrumen & $\begin{array}{c}\text { Pearson } \\
\text { Correlation }\end{array}$ & Keterangan \\
\hline \multirow{4}{*}{$\begin{array}{c}\text { Promosi } \\
\text { Penjualan }\left(X_{1}\right)\end{array}$} & $\mathrm{X}_{1.1}$ & 0,809 & Valid \\
\hline & $\mathrm{X}_{1} .2$ & 0,771 & Valid \\
\hline & $\mathrm{X}_{1} .3$ & 0,649 & Valid \\
\hline & $\mathrm{X}_{1.4}$ & 0,715 & Valid \\
\hline \multirow{4}{*}{$\begin{array}{c}\text { Penataan } \\
\text { Produk }\left(X_{2}\right)\end{array}$} & $\mathrm{X}_{2.1}$ & 0,610 & Valid \\
\hline & $\mathrm{X}_{2.2}$ & 0,692 & Valid \\
\hline & $X_{2} .3$ & 0,760 & Valid \\
\hline & $\mathrm{X}_{2.4}$ & 0,826 & Valid \\
\hline \multirow{5}{*}{$\begin{array}{c}\text { Suasana Mall } \\
\left(\mathbf{X}_{3}\right)\end{array}$} & $\mathrm{X}_{3.1}$ & 0,723 & Valid \\
\hline & $\mathrm{X}_{3} .2$ & 0,622 & Valid \\
\hline & $X_{3} .3$ & 0,426 & Valid \\
\hline & $\mathrm{X}_{3.4}$ & 0,711 & Valid \\
\hline & $X_{3.5}$ & 0,749 & Valid \\
\hline \multirow{5}{*}{$\begin{array}{c}\text { Pembelian } \\
\text { Tidak } \\
\text { Terencana }(Y)\end{array}$} & Y1 & 0,788 & Valid \\
\hline & $\mathrm{Y} 2$ & 0,936 & Valid \\
\hline & Y3 & 0,821 & Valid \\
\hline & Y4 & 0,933 & Valid \\
\hline & Y5 & 0,897 & Valid \\
\hline
\end{tabular}

Dapat dilihat pada tabel $4.1 \mathrm{di}$ atas pada kolom pearson correlation pada butir-butir item pernyataan variabel promosi penjualan, penataan produk, dan suasana mall yang lebih besar dari standar validitas yaitu 0,30. Maka seluruh item pernyataan dinyatakan valid karena telah memenuhi kriteria tersebut.

\section{Uji Reliabilitas}

Reliabilitas menunjukkan konsistensi dan kestabilan dari suatu skala. Pengukuran analisis reliabilitas atau uji keandalan ini merupakan indikasi sejauh mana pengukuran tersebut memberikan hasil yang relatif sama apabila dilakukan pengukuran ulang terhadap subyek yang sama pada waktu yang berbeda. Untuk mengetahui tingkat reliabilitas dalam analisis ini digunakan koefisien Cronbach's Alpha (Azwar, 1986).

Berdasarkan pada ketentuan dari Cronbach's Alpha lebih dari 0,60. Butir item pernyataan yang dimasukkan dalam uji reliabilitas terdiri 4 item pernyataan mengenai promosi penjualan, 4 item pernyataan mengenai penataan produk, 5 item pernyataan mengenai suasana mall, dan 5 item pernyataan mengenai pembelian tidak terencana. Hasil uji 
reliabilitas mengenai variabel tersebut dinyatakan dalam bentuk tabel sebagai berikut:

Tabel 4.2

Uji Reliabilitas

\begin{tabular}{|c|c|c|}
\hline Variabel & Cronbach's Alpha & Keterangan \\
\hline Promosi Penjualan $\left(\mathbf{X}_{\mathbf{1}}\right)$ & 0,712 & Reliabel \\
\hline Penataan Produk $\left(\mathbf{X}_{\mathbf{2}}\right)$ & 0,699 & Reliabel \\
\hline Suasana Mall $\left(\mathbf{X}_{\mathbf{3}}\right)$ & 0,653 & Reliabel \\
\hline $\begin{array}{c}\text { Pembelian Tidak } \\
\text { Terencana (Y) }\end{array}$ & 0,923 & Reliabel \\
\hline
\end{tabular}

Dapat dilihat pada tabel 4.2 di atas pada kolom Cronbach's Alpha pada butir-butir pernyataan variabel promosi penjualan, penataan produk, suasana mall, dan pembelian tidak terencana yaitu lebih besar dari standar reliabilitas yaitu Cronbach's Alpha $>0,60$.

\section{Analisis Regresi Linier Berganda}

\section{Tabel 4.3}

Analisis Regresi Linier

\begin{tabular}{|c|c|c|c|c|c|c|}
\hline \multirow{2}{*}{\multicolumn{2}{|c|}{ Model }} & \multicolumn{2}{|c|}{$\begin{array}{l}\text { Unstandardized } \\
\text { Coeffients }\end{array}$} & \multirow{2}{*}{\begin{tabular}{|c|}
$\begin{array}{l}\text { Standardized } \\
\text { Coefficients }\end{array}$ \\
Beta \\
\end{tabular}} & \multirow[b]{2}{*}{$t$} & \multirow[b]{2}{*}{ Sig } \\
\hline & & B & Std. Error & & & \\
\hline 1 & (Constant) & 2,142 & 4,009 & & ,534 &, 595 \\
\hline & $\mathrm{X} 1$ & 0,395 & 0,194 & ,213 & 2,032 & ,046 \\
\hline & $\mathrm{X} 2$ & 0,315 & 0,150 & ,225 & 2,099 & ,039 \\
\hline & $\mathrm{X} 3$ & 0,339 & 0,157 & ,238 & 2,161 & ,034 \\
\hline
\end{tabular}

Berdasarkan tabel 4.3 di atas, persamaan regresi sebagai berikut ini:

$\mathrm{Y}=\mathrm{a}+\mathrm{b}_{1} \mathrm{X}_{1}+\mathrm{b}_{2} \mathrm{X}_{2}+\mathrm{b}_{3} \mathrm{X}_{3}$

$\mathrm{Y}=2,142+0,395 \mathrm{X}_{1}+0,315 \mathrm{X}_{2}+0,339 \mathrm{X}_{3}$

Hasil dari persamaan regresi di atas dapat dijelaskan sebagai berikut:

1) Konstanta (a)

Konstanta yang diperoleh dalam penelitian ini sebesar 2,142 yang memiliki arti bahwa variabel promosi penjualan, penataan produk, dan suasana mall mempunyai nilai yang sama dengan nol, maka besarnya variabel dukungan pembelian tidak terencana adalah 2,142.
2) Variabel Promosi Penjualan $\left(X_{1}\right)$

Dalam penelitian ini koefisien regresi $\left(b_{1}\right)$ pada variabel promosi penjualan $\left(\mathrm{X}_{1}\right)$ bersifat positif dengan koefisien regresi sebesar 0,395. Hal tersebut artinya bahwa setiap peningkatan sebesar satu satuan, maka variabel pembelian tidak terencana (Y) akan meningkatkan sebesar 0,395 satuan dengan asumsi variabel lain konstan. Nilai yang positif pada variabel promosi penjualan $\left(\mathrm{X}_{1}\right)$ menunjukkan hubungan yang searah. Artinya semakin meningkatnya promosi penjualan, maka pembelian tidak terencana akan semakin meningkat.

3) Variabel Penataan Produk $\left(X_{2}\right)$

Dalam penelitian ini koefisien regresi $\left(b_{2}\right)$ pada variabel penataan produk $\left(\mathrm{X}_{2}\right)$ bersifat positif dengan koefisien regresi sebesar 0,315. Hal tersebut artinya bahwa setiap peningkatan sebesar satu satuan, maka variabel pembelian tidak terencana (Y) akan meningkatkan sebesar 0,315 satuan dengan asumsi variabel lain konstan. Nilai yang positif pada variabel penataan produk $\left(\mathrm{X}_{2}\right)$ menunjukkan hubungan yang searah. Artinya semakin meningkatnya penataan produk, maka pembelian tidak terencana semakin meningkat.

4) Variabel Suasana Mall $\left(X_{3}\right)$

Dalam penelitian ini koefisien regresi $\left(b_{1}\right)$ pada variabel suasana mall $\left(\mathrm{X}_{3}\right)$ bersifat positif dengan koefisien regresi sebesar 0,339 . Hal tersebut artinya bahwa setiap peningkatan sebesar satu satuan, maka variabel pembelian tidak terencana $(\mathrm{Y})$ akan meningkatkan sebesar 0,339 satuan dengan asumsi variabel lain konstan. Nilai yang positif pada variabel suasana mall $\left(\mathrm{X}_{3}\right)$ menunjukkan hubungan yang searah. Artinya semakin meningkatnya suasana mall, maka pembelian tidak terencana akan semakin meningkat. 


\section{Uji Hipotesis}

\section{Uji Parsial (Uji T)}

\section{Tabel 4.4}

Uji Parsial

\begin{tabular}{|l|l|l|l|}
\hline \multicolumn{2}{|l|}{ Model } & t & \multicolumn{1}{l|}{ Sig } \\
\hline 1 & (Constant) &, 534 &, 595 \\
\hline
\end{tabular}

\begin{tabular}{|l|l|r|r|}
\hline & X1 & 2,032 &, 046 \\
\hline & X2 & 2,099 &, 039 \\
\hline & X3 & 2,161 &, 034 \\
\hline
\end{tabular}

Berdasarkan data uji-t pada tabel 4.4 di atas, maka dapat ditarik kesimpulan:

1) Hasil pengujian di atas pada tabel 4.4 menunjukkan bahwa variabel promosi penjualan diperoleh thitung $=2,032$ dan diperoleh $\mathrm{t}_{\text {tabel }}=1,99210$. Maka dapat disimpulkan bahwa $\mathrm{t}_{\text {hitung }}$ lebih besar dari $\mathrm{t}_{\text {tabel }}$. Perolehan signifikasi atau $p$-value sebesar 0,046 dengan menggunakan batas signifikasi $(\alpha=0,05)$ atau yang dapat dikatakan nilai $\mathrm{p}$-value tersebut di bawah taraf $(\alpha=0,05)$ yang berarti $\mathrm{H}_{0}$ ditolak dan $\mathrm{H}_{1}$ diterima. Dapat disimpulkan bahwa hipotesis pertama yang mengatakan promosi penjualan berpengaruh positif terhadap pembelian tidak terencana diterima.

2) Hasil pengujian di atas tabel 4.4 menunjukkan bahwa variabel penataan produk diperoleh $\mathrm{t}_{\text {hitung }}=$ 2,099 dan diperoleh $\mathrm{t}_{\text {tabel }}=1,99210$. Maka dapat disimpulkan bahwa $\mathrm{t}_{\text {hitung }}$ lebih besar dari $\mathrm{t}_{\text {tabel }}$. Peroleh signifikan atau $p$-value sebesar 0,039 dengan menggunakan batas signifikasi $(\alpha=0,05)$ atau yang dapat dikatakan nilai $p$-value tersebut di bawah taraf $(\alpha=0,05)$ yang berarti $\mathrm{H}_{0}$ ditolak dan $\mathrm{H}_{2}$ diterima. Dapat disimpulkan bahwa hipotesis kedua yang mengatakan penataan produk berpengaruh positif terhadap pembelian tidak terencana diterima.

3) Hasil pengujian di atas tabel 4.4 menunjukkan bahwa variabel suasana mall diperoleh $t_{\text {hitung }}=2,161$ dan diperoleh $\mathrm{t}_{\text {tabel }}=1,99210$. Maka dapat disimpulkan bahwa $t_{\text {hitung }}$ lebih besar dari $\mathrm{t}_{\text {tabel. }}$. Peroleh signifikasi atau $p$-value sebesar 0,034 dengan menggunakan batas signifikasi $(\alpha=0,05)$ atau dapat dikatakan nilai $p$-value tersebut di bawah taraf $(\alpha=0,05)$ yang berarti $\mathrm{H}_{0}$ ditolak dan $\mathrm{H}_{3}$ diterima. Dapat disimpulkan bahwa hipotesis ketiga yang mengatakan suasana mall berpengaruh positif terhadap pembelian tidak terencana diterima.

\section{Uji Simultan (Uji F)}

Tabel 4.5

Uji Simultan

\begin{tabular}{|l|c|c|c|c|c|}
\hline Model & $\begin{array}{c}\text { Sum of } \\
\text { Squares }\end{array}$ & L1 & Mean Square & F & Sig \\
\hline Regression & 111,510 & 3 & 37,170 & 7,249 & 0,000 \\
\hline Residual & 389,677 & 76 & 5,127 & & \\
\hline Total & 501,188 & 79 & & & \\
\hline
\end{tabular}

Dari tabel 4.5 diatas didapatkan hasil $F_{\text {hitung }}$ sebesar 7,249 dengan tingkat signifikan 0,000 . Uji $F$ dilakukan dengan membandingkan $\mathrm{F}_{\text {hitung }}$ dengan $\mathrm{F}_{\text {tabel }}$ pada tingkat signifikan sebesar $5 \%$ atau 0,05 , dengan menggunakan rumus $\mathrm{df} 1=\mathrm{k}-$ 1 dan $\mathrm{df}_{2}=\mathrm{n}-\mathrm{k}$, dimana $\mathrm{k}$ merupakan jumlah variabel dependen dan variabel independen dan $\mathrm{n}$ merupakan jumlah responden.

Jika nilai $\mathrm{df}_{1}=\mathrm{k}-1$

$$
\begin{aligned}
& \mathrm{df}_{1}=4-1 \\
& \mathrm{df}_{1}=3
\end{aligned}
$$

Jika nilai $\mathrm{df}_{2}=\mathrm{n}-\mathrm{k}$

$$
\begin{aligned}
& \mathrm{df}_{2}=80-4 \\
& \mathrm{df}_{2}=76
\end{aligned}
$$

Maka $\mathrm{F}_{\text {tabel }} 0,05(3 ; 76)=2,72$

Maka dapat disimpulkan bahwa $\mathrm{F}_{\text {hitung }}$ sebesar 7,249 $>\mathrm{F}_{\text {tabel }}$ 2,72. Perolehan 
signifikasi atau $p$-value sebesar 0,000 dengan menggunakan batas signifikasi ( $\alpha$ $=0,05)$ atau dapat dilakukan nilai $p$-value tersebut di bawah taraf $(\alpha=0,05)$. Dari hasil tersebut dapat disimpulkan bahwa secara simultan atau bersama-sama promosi penjualan $\left(\mathrm{X}_{1}\right)$, penataan produk $\left(\mathrm{X}_{2}\right)$, dan suasana mall $\left(\mathrm{X}_{3}\right)$ memiliki pengaruh signifikan terhadap pembelian tidak terencana $(\mathrm{Y})$.

\section{Uji Koefisien Determinasi}

Tabel 4.6

Uji Koefisien Determinasi

\begin{tabular}{|l|r|r|r|r|}
\hline Model & $\mathrm{R}$ & R Square & \multicolumn{1}{|c|}{$\begin{array}{c}\text { Adjusted } R \\
\text { Square }\end{array}$} & $\begin{array}{l}\text { Std. Error of the } \\
\text { Estimate }\end{array}$ \\
\hline 1 &, $472^{\mathrm{a}}$ &, 222 &, 192 & 2,264 \\
\hline
\end{tabular}

Dari tabel 4.6 menunjukkan bahwa hasil pengujian determinasi $\mathrm{R}_{2}$ yang dapat dilihat pada kolom Adjusted $R$ Square. Adjusted $R$ Square digunakan karena pada penelitian ini dari menggunakan lebih dari variabel bebas. Jumlah Adjusted $R$ Square sebesar 0,192, yang artinya $19,2 \%$ variabel dependen yaitu pembelian tidak terencana dapat dijelaskan oleh variabel independen yang meliputi promosi penjualan, penataan produk, dan suasana mall. Sedangkan sisanya yaitu sebesar $80,8 \%$ dapat dijelaskan melalui variabelvariabel lain tidak diteliti dalam penelitian ini.

\section{Pembahasan}

\section{Pengaruh Positif Promosi Penjualan terhadap Pembelian Tidak Terencana}

Berdasarkan hasil analisis regresi berganda pada tabel 4.3 menunjukkan tingkat signifikasi promosi penjualan sebesar 0,046, maka 0,046<0,05 dengan nilai beta 0,394 serta nilai thitung 2,032> $\mathrm{t}_{\text {tabel }}$ 1,99210. Artinya, promosi penjualan berpengaruh positif terhadap pembelian tidak terencana. Dengan ini dapat disimpulkan bahwa semakin baik promosi penjualan, maka semakin tinggi pengaruh terhadap pembelian tidak terencana.
Hipotesis pertama yang menyatakan promosi penjualan berpengaruh positif terhadap pembelian tidak terencana diterima. Hasil penelitian ini mendukung penelitian sebelumnya yang dilakukan oleh Temaja (2015) dan Oky (2016) yang menunjukkan bahwa promosi penjualan berpengaruh positif terhadap pembelian tidak terencana.

Promosi penjualan yang dilakukan perusahaan dengan memberikan diskon dan cashback pada produk yang dijual dapat menjadikan pengunjung dapat tertarik dan berminat membeli karena konsumen sangat senang membeli barang yang sedang didiskon, meskipun semula konsumen tidak berminat memberi barang tersebut. Promosi penjualan adalah suatu komunikasi informasi yang digunakan oleh perusahaan untuk mempromosikan produk atau barang ke konsumen dengan tujuan untuk merubah sikap dan tingkah laku pembeli, yang sebelumnya tidak paham menjadi paham sehingga menjadi pembeli dan mengingat produk tersebut (Kurniawan, 2013).

Pembelian tidak terencana dapat diartikan sebelumnya dengan memiliki kecenderungan konsumen membeli dengan spontan, reflek, tiba-tiba, otomatis, dan konsumen melakukan pembelian tidak terencana dapat terjadi dimana dan kapanpun. Seorang konsumen saat melakukan pembelian tidak terencana dalam mengambil keputusan untuk membeli produk hanya berpikir jangka pendek untuk membeli.

\section{Pengaruh Positif Penataan Produk terhadap Pembelian Tidak Terencana}

Berdasarkan hasil analisis regresi berganda pada tabel 4.3 menunjukkan tingkat signifikasi penataan produk sebesar 0,039, maka 0,039<0,05 dengan nilai beta 0,315 serta nilai $t_{\text {hitung }} 2,099$ $>\mathrm{t}_{\text {tabel }} 1,99210$ mempunyai arti bahwa penataan produk berpengaruh positif terhadap pembelian tidak terencana. 
Dengan ini dapat disimpulkan bahwa semakin baik penataan produk, maka semakin tinggi pengaruh terhadap pembelian tidak terencana. Hipotesis kedua yang menyatakan penataan produk berpengaruh positif terhadap pembelian tidak terencana diterima. Hasil penelitian ini mendukung penelitian sebelumnya yang dilakukan oleh Potoh (2017) yang menunjukkan penataan produk berpengaruh positif terhadap pembelian tidak terencana.

Hal ini memberikan implikasi bahwa penataan dan pengaturan produk pada Ramayana Department Store senantiasa memperhatikan unsur pengelompokkan jenis dan kegunaan produk, kerapian dan keindahan yang bertujuan untuk memudahkan konsumen dalam melakukan pencarian produk, menonjolkan jenis dan merek produk, meningkatkan penjualan, dan memperkenalkan produk baru sehingga dapat memberikan manfaat yang positif bagi Ramayana Department Store.

Penataan produk yang menarik, rapi, tertata akan dapat mempengaruhi psikis konsumen. Penataan produk adalah usaha yang dilakukan untuk menata barang-barang yang akan ditawarkan kepada konsumen agar merasa tertarik untuk melihat dan memutuskan untuk melakukan pembelian (Sopiah, 2008). Penataan produk bagi mall bertujuan untuk menarik perhatian konsumen dengan cara menggunakan tata letak barang yang menarik. Sedangkan pembelian tidak terencana adalah tindakan pembelian yang sebelumnya tidak diakui secara sadar sebagai hasil dari pertimbangan, atau niat pembelian yang terbentuk sebelumnya memasuki mall (Mowen, 2002) atau bisa juga dikatakan tiba-tiba dan tidak direncanakan sebelumnya untuk melakukan pembelian yang secara langsung tanpa banyak pertimbangan terlebih dahulu. Ramayana Department Store melakukan penataan produk untuk mempengaruhi konsumen melakukan pembelian spontan dengan melihat tata letak barang yang menarik sehingga konsumen melakukan pembelian tidak terencana.

\section{Pengaruh Positif Suasana Mall terhadap Pembelian Tidak Terencana}

Berdasarkan hasil analisis regresi berganda pada tabel 4.3 menunjukkan tingkat signifikasi suasana mall sebesar 0,034 , maka $0,034<0,05$ dengan nilai beta 0,0339 serta nilai $\mathrm{t}_{\text {hitung }} 2,161>\mathrm{t}_{\text {tabel }} 1,99210$. Artinya, suasana mall berpengaruh positif terhadap pembelian tidak terencana. Dengan ini dapat disimpulkan bahwa semakin baik suasana mall, maka semakin tinggi pengaruh terhadap pembelian tidak terencana. Hipotesis ketiga menyatakan suasana mall berpengaruh positif terhadap pembelian tidak terencana diterima. Hasil penelitian ini mendukung hasil penelitian sebelumnya yang dilakukan oleh Oky (2015) dan Temaja (2015) yang menunjukkan bahwa suasana mall berpengaruh positif terhadap pembelian tidak terencana.

Suasana mall berpengaruh positif karena memiliki program yang baik, yaitu membuat suasana Ramayana Department Store menjadi lebih tertata dengan lebih baik, pencahayaan, bersih, dan berpendingin udara. Keberadaan kondisi di atas akan menambah minat konsumen untuk lebih betah berada di mall, sehingga dapat menimbulkan pembelian tidak terencana.

Suasana mall berarti bauran pemasaran ritel yang terkait dalam hal penciptaan suasana belanja. Suasana mall merupakan kunci dalam menarik dan membuat konsumen terkesan dengan pengalaman berbelanja di dalam gerai (Coley, 2003). Ramayana Department Store mampu mengelola suasana mallnya dengan sedemikian rupa sehingga meningkatkan kunjungan konsumen. Oleh karena itu, Ramayana Department 
Store harus membuat suasananya terlihat menarik saat di kunjungi konsumen. Sedangkan pembelian tidak terencana bagi perusahaan adalah konsumen yang melakukan pembelian di Ramayana Department Store dengan didukung adanya suasana mall yang nyaman, pencahayaan, pendingin ruangan, dan tata warna dalam mall tersebut mempengaruhi konsumen dalam melakukan pembelian tidak terencana.

4. Pengaruh Signifikan Promosi Penjualan, Penataan Produk, dan Suasana Mall secara Simultan terhadap Pembelian Tidak Terencana

Dari tabel 4.5 didapatkan hasil $\mathrm{F}_{\text {hitung }}$ sebesar 7,249 dengan tingkat signifikasi 0,000. Maka dapat disimpulkan bahwa $\mathrm{F}_{\text {hitung }}$ sebesar 7,249 $>\mathrm{F}_{\text {tabel }}$ 2,72. Perolehan signifikan atau $p$-value sebesar 0,000 dengan menggunakan batas signifikasi $(\alpha$ $=0,05)$ atau dapat dilakukan nilai $p$-value tersebut di bawah taraf $(\alpha=0,05)$. Dari hasil tersebut dapat disimpulkan bahwa secara simultan atau bersama-sama promosi penjualan $\left(\mathrm{X}_{1}\right)$, penataan produk $\left(\mathrm{X}_{2}\right)$, dan suasana mall $\left(\mathrm{X}_{3}\right)$ memiliki pengaruh signifikan terhadap pembelian tidak terencana $(\mathrm{Y})$.

\section{KESIMPULAN DAN SARAN}

\section{Kesimpulan}

Berdasarkan hasil penelitian di atas, maka dapat disimpulkan bahwa:

1. Hipotesis pertama yang mengatakan promosi penjualan berpengaruh positif terhadap pembelian tidak terencana diterima. Hal ini dibuktikan dengan perolehan koefisien regresi sebesar 0,395 dan dengan nilai $p$-value sebesar 0,046 yang berarti lebih kecil dari taraf signifikasi yang telah ditentukan $(\alpha=0,05)$
2. Hipotesiskeduayangmengatakanpenataan produk berpengaruh positif terhadap pembelian tidak terencana diterima. Hal ini dibuktikan dengan perolehan koefisien regresi sebesar 0,315 dan dengan nilai p-value sebesar 0,039 yang berarti lebih kecil dari taraf signifikasi yang telah ditentukan $(\alpha=0,05)$.

3. Hipotesis ketiga yang mengatakan suasana mall berpengaruh positif terhadap pembelian tidak terencana diterima. Hal ini dibuktikan dengan koefisien regresi sebesar 0,395 dan dengan nilai $p$-value sebesar 0,034 yang berarti lebih kecil dari taraf signifikasi yang telah ditentukan $(\alpha=0,05)$.

4. Hipotesis keempat yang mengatakan promosi penjualan, penataan produk, dan suasana mall secara bersamasama berpengaruh signifikan terhadap pembelian tidak terencana diterima. Hal ini dibuktikan dengan perolehan hasil uji F sebesar 7, 249 dan memiliki nilai $p$-value sebesar 0,000 yang berarti lebih kecil dari taraf signifikasi yang telah ditentukan $(\alpha=0,05)$.

\section{Saran}

Saran yang dapat diberikan dalam penelitian ini diantaranya:

1. Ramayana Department Store harus meningkatkan promosi penjualan, karena jika promosinya bagus dapat membuat konsumen memiliki ketertarikan melakukan pembelian di Ramayana, dan konsumen tidak beralih ke department store lain.

2. Ramayana Department Store selalu meningkatkan penataan produk dan secara rutin memperbaharui penataan produk untuk lebih menarik konsumen untuk melakukan pembelian produk di dalam mall Ramayana, sehingga konsumen tidak merasa kebingungan saat memilih produk yang tertata lebih rapi.

3. Ramayana Department Store selalu memperhatikan suasana mall guna untuk menambahkan keindahan atau suasana 
yang menarik berada di Ramayana Department Store, sehingga konsumen merasa nyaman berada di dalam Ramayana Department Store.

\section{DAFTAR PUSTAKA}

Alma, B. (2018). Manajemen Pemasaran \& Pemasaran Jasa. Bandung: Alpabeta.

Arikunto, S. (2006). Metode Penelitian Kuantitatif. Jakarta: Bumi Aksara.

Azwar, S. (1986). Validitas dan Reliabilitas. Jakarta: Rineka Cipta.

Clow, K. E., \& Baack, D. (2012). Integrated Advertising, Promotion, and Marketing Communications. Printice Hall, England: 5th ed.

Coley, A \& Burgerss. B. (2003). Gender Differences in Cognitive and Affective Buying. Journal of Fashion Marketing and Management. ISSN: 1361-2026.

Ghozali, Imam. (2012). Aplikasi Analisis Multivariate dengan Program IBM SPSS. Yogyakarta: Universitas Diponegoro.

Honezty, F. (2018). Sejarah Berdirinya Ramayana Department Store. (Online). (http://Ramayanadeptstore.blogspot. com/2018/10/sejarah-berdirinyaramayana.html? $\mathrm{m}=1$, diunduh pada 08 November 2018).

Kurniawan, D., \& Kunto, S. Y. (2013). Pengaruh Promosi dan Store Atmosphere terhadap Impulse Buying dengan Shopping Emotion sebagai Variabel Intervening Studi Kasus di Matahari Department Store Cabang Supermall Surabaya. Jurnal Manajemen Pemasaran Petra, Vol 1 No 2.
Mowen, J.C. \& Minor, M. (2001). Perilaku Konsumen. Jakarta: Erlangga.

Muruganantham, G., \& Bhakat, R. S. (2013). A Review of Impulse Buying Behavior. International Journal of Marketing Studies. Vol 5 No 3 ISSN 1918-719X E-ISSN 1918-7203.

Nofiawaty dan Yuliandi, B. (2014). Pengaruh Store Atmosphere terhadap Keputusan Pembelian Konsumen pada Outlet Nyenyes Palembang. Jurnal Manajemen dan Bisnis Sriwijaya. Vol 12. No 1.

Okky, Ratna Utami \& Ni Made Rastini. (2015). Pengaruh Variabel Demografi, Kualitas Pelayanan, Atmosfer Toko pada Impulse buying di Hypermart Mall. E-Jurnal Manajemen Unud. Vol.4, No. 5. ISSN 2302-8912.

Potoh, M. E., Moniharapon, S., \& Roring, f. (2017). Pengaruh Display dan Store Atmosphere terhadap Impulse Buying pada Konsumen Matahari Department Store Mega Mall Manado. Jurnal EMBA, Vol.5 No.2 ISSN 2303-1174.

Reza, Iqbal. (2017). 4 Department Store Ini Gulung Tikar karena Alasan yang Sama. (Online), (http://www.idtimes. com/business/economy/reza-iqbal/4Department-store-gulung-tikar, diunduh 07 November 2018).

Siagian, Dergibson. (2000). Metode Statistika untuk Bisnis dan Ekonomi. Jakarta: PT Gramedia.

Sopiah dan Syihabudin. 2008. Manajemen Bisnis Ritel. Jakarta: Andi.

Sugiyono. (2004). Metode Penelitian. Bandung: Alfabeta. 
Sugiyono. (2010). Metode Penelitian Kuantitatif Kualitatif R\&D. Bandung: CV Alfabeta.

Sugiyono. (2012). Metode Penelitian Kuantitatif, Kualitatif, dan $R \& D$. Bandung: Alfabeta.

Sugiyono. (2013). Metode Penelitian Manajemen. Bandung: Penerbit Alfabeta.

Temaja, I Km Wisnu Bayu, dkk. (2015). Pengaruh Fashion Involvement, Atmosfer Toko dan Promosi Penjualan terhadap Impulse Buying pada Matahari Department Store di Kota Denpasar. E-Jurnal Manajemen Unud. Vol.4, No. 6, ISSN: 2302-8912.

Utami, Chistina Whidya. (2010). Manajemen Ritel: Strategi dan Implementasi Operasional Bisnis Ritel Modern di Indonesia. Jakarta: Salemba Empat.

Utami, O. R., \& Rastini, N. M., (2015). Pengaruh Variabel Demografi, Kualitas Layanan, Atmosfer Toko pada Impulse Buying di Hypermart Mall. E-Jurnal Manajemen Unud Vol 4, 1229-1237. 
WURI PLANGI AYATINA, SAPTANINGSIH SUMARMI

Analisis Pengaruh Promosi Penjualan, Penataan Produk, dan Suasana Mall terhadap Pembelian Tidak Terencana (Studi Kasus Ramayana Department Store Yogyakarta) 